ARTICLE

\title{
Operando high-pressure investigation of size-controlled CuZn catalysts for the methanol synthesis reaction
}

Núria J. Divins (D) 1,6,7, David Kordus (iD) 1,2,7, Janis Timoshenko (D) 2, Ilya Sinev", loannis Zegkinoglou (iD) ${ }^{1}$,

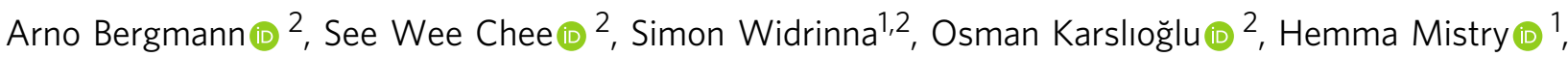
Mauricio Lopez Luna2, Jian Qiang Zhong (1) 2, Adam S. Hoffman ${ }^{3}$, Alexey Boubnov ${ }^{3}$, J. Anibal Boscoboinik (i) 4 , Marc Heggen ${ }^{5}$, Rafal E. Dunin-Borkowski (i) ${ }^{5}$, Simon R. Bare (iD ${ }^{3} \&$ Beatriz Roldan Cuenya (i) ${ }^{2 \times}$

\begin{abstract}
Although $\mathrm{Cu} / \mathrm{ZnO}$-based catalysts have been long used for the hydrogenation of $\mathrm{CO}_{2}$ to methanol, open questions still remain regarding the role and the dynamic nature of the active sites formed at the metal-oxide interface. Here, we apply high-pressure operando spectroscopy methods to well-defined $\mathrm{Cu}$ and $\mathrm{Cu}_{0.7} \mathrm{Zn}_{0.3}$ nanoparticles supported on $\mathrm{ZnO} / \mathrm{Al}_{2} \mathrm{O}_{3}$, $\gamma-\mathrm{Al}_{2} \mathrm{O}_{3}$ and $\mathrm{SiO}_{2}$ to correlate their structure, composition and catalytic performance. We obtain similar activity and methanol selectivity for $\mathrm{Cu} / \mathrm{ZnO} / \mathrm{Al}_{2} \mathrm{O}_{3}$ and $\mathrm{CuZn} / \mathrm{SiO}_{2}$, but the methanol yield decreases with time on stream for the latter sample. Operando X-ray absorption spectroscopy data reveal the formation of reduced $\mathrm{Zn}$ species coexisting with $\mathrm{ZnO}$ on $\mathrm{CuZn} / \mathrm{SiO}_{2}$. Near-ambient pressure X-ray photoelectron spectroscopy shows $\mathrm{Zn}$ surface segregation and the formation of a $\mathrm{ZnO}$-rich shell on $\mathrm{CuZn} / \mathrm{SiO}_{2}$. In this work we demonstrate the beneficial effect of $Z n$, even in diluted form, and highlight the influence of the oxide support and the $\mathrm{Cu}-\mathrm{Zn}$ interface in the reactivity.
\end{abstract}

\footnotetext{
${ }^{1}$ Department of Physics, Ruhr University Bochum, Bochum, Germany. ${ }^{2}$ Department of Interface Science, Fritz-Haber Institute of the Max Planck Society, Berlin, Germany. ${ }^{3}$ Stanford Synchrotron Radiation Lightsource, SLAC National Accelerator Laboratory, Menlo Park, CA, USA. ${ }^{4}$ Center for Functional Nanomaterials, Brookhaven National Laboratory, Upton, New York, USA. ${ }^{5}$ Ernst Ruska-Centre for Microscopy and Spectroscopy with Electrons and Peter Grünberg Institute, Forschungszentrum Jülich, Jülich, Germany. ${ }^{6}$ Present address: Institute of Energy Technologies, Universitat Politècnica de Catalunya, EEBE, Barcelona, Spain. ${ }^{7}$ These authors contributed equally: Núria J. Divins, David Kordus. ${ }^{\varpi_{e}}$ mail: roldan@fhi-berlin.mpg.de
} 
$\mathrm{T}$ he utilization of fossil fuels as the main energy source gives rise to serious environmental issues, including global warming caused by the continuously increasing level of atmospheric $\mathrm{CO}_{2}$. The hydrogenation of $\mathrm{CO}_{2}$ is an important process to valorize $\mathrm{CO}_{2}$ by converting it into useful chemicals and fuels, such as methanol ${ }^{1-4}$. Methanol is presently industrially synthesized from $\mathrm{CO}_{2}, \mathrm{CO}$, and $\mathrm{H}_{2}$ at pressures between 50 and $100 \mathrm{bar}$ and temperatures between 200 and $300^{\circ} \mathrm{C}$ using $\mathrm{Cu} / \mathrm{ZnO} / \mathrm{Al}_{2} \mathrm{O}_{3}$ catalysts $^{5-7}$.

Although $\mathrm{Cu} / \mathrm{ZnO}$-based catalysts have been long studied, the role and the dynamic nature of the active sites that originate at the metal-oxide interface under the strongly reducing reaction conditions are still under debate. It has been shown that $\mathrm{Cu}$-based catalysts containing $\mathrm{ZnO}$ are more active than their $\mathrm{ZnO}$-free counterparts ${ }^{8}$ and that $\mathrm{ZnO}$ both enhances the dispersion of the $\mathrm{Cu}$ nanoparticles (NPs), and acts as an electronic promoter ${ }^{8,9}$ through a strong metal-support interaction ${ }^{8-10}$. This promoting effect of $\mathrm{Zn}$ has been attributed to the $\mathrm{Zn}$ being present in a number of different configurations: the formation of graphitic $\mathrm{ZnO}_{\mathrm{x}}$ layers on $\mathrm{Cu} \mathrm{NPs}{ }^{11}$, metallic $\mathrm{Zn}$ atoms within the $\mathrm{Cu} \mathrm{NP}$ surface $^{12}, \mathrm{CuZn}$ alloy formation ${ }^{13}, \mathrm{Zn}$-decoration of stepped $\mathrm{Cu}$ surfaces $^{1}$, or the formation of $\mathrm{ZnO}$ at the interface with $\mathrm{Cu}$ in single crystals ${ }^{3,14}$. A strong correlation between the $\mathrm{Zn}$ coverage on $\mathrm{Cu}$ NPs and the methanol synthesis activity was also reported ${ }^{2}$. Furthermore, the structure-sensitivity and size-dependent activity for this reaction were shown for $\mathrm{Cu}$ and CuZn-based catalysts 4 .

Heterogeneous catalysts are dynamic entities and adapt their morphology and electronic structure to the chemical potential of the surrounding gaseous atmosphere ${ }^{15,16}$. Thus, for methanol synthesis catalysts, operando studies in pressure regimes that are industrially relevant (20-100 bar), as the ones discussed in the present work, are key to overcome the "pressure gap"15,17-25, as they probe $\mathrm{Cu}$ and $\mathrm{Zn}$ under their actual working state, unraveling their active chemical and structural state. Investigations on $\mathrm{Cu} / \mathrm{ZnO}$ systems revealed the presence of poorly crystalline $\mathrm{ZnO}$ interacting with $\mathrm{Cu}^{15}$, reversible changes of the $\mathrm{Cu}$ NP morphology depending on the reaction conditions ${ }^{17,23}$, CuZn bulk alloy formation under severe reduction conditions $\left(600^{\circ} \mathrm{C}\right.$ in $\mathrm{CO} /$ $\left.\mathrm{H}_{2}\right)^{17,26}$, and $\mathrm{ZnO}$ reduction and a stronger $\mathrm{CuZn}$ interaction for catalysts supported on $\mathrm{SiO}_{2}{ }^{19-21}$. Interestingly, even at subatmospheric pressures $(1-2 \mathrm{mbar})^{27}$, the dynamic behavior of these catalysts has also been corroborated with the observation of wetting/non-wetting of $\mathrm{Cu}$ NPs on $\mathrm{ZnO}^{28}$. Despite the tremendous effort dedicated to the investigation of this reaction, questions still remain on whether metallic $\mathrm{Zn} /$ brass is present under industrially relevant reaction conditions, its role in the reaction selectivity, and whether $\mathrm{ZnO}$ is needed as a part of the support, or small $\mathrm{ZnO}$ ensembles in direct contact with $\mathrm{Cu}$ within a NP can also serve to activate $\mathrm{CO}_{2}$.

To address these questions, here we use morphologically and chemically well-defined $\mathrm{Cu}$ and CuZn NP catalysts that help close the materials gap between the heterogeneous industrial catalysts and the model single-crystal systems previously studied, while also addressing the pressure gap through operando spectroscopic characterization at industrially relevant high-pressure conditions. The small NP size chosen in our study allows us to investigate the changes occurring at the surface and near-surface region of the NPs by the bulk-sensitive technique X-ray absorption spectroscopy (XAS), since the fraction of atoms at the surface of Cu NPs of ca. $3 \mathrm{~nm}$ is $\sim 60 \%{ }^{29}$. In this way, we are able to shed light on the dynamic evolution of the metal NP/oxide support interface during $\mathrm{CO}_{2}+\mathrm{CO}$ hydrogenation.

\section{Results}

Model catalysts synthesis and characterization. Five catalysts, designed to be analogous to the commercial $\mathrm{Cu} / \mathrm{ZnO} / \mathrm{Al}_{2} \mathrm{O}_{3}$ catalyst, composed of size-controlled NPs were synthesized to investigate the different components and interactions of the industrial catalyst. Monometallic $\mathrm{Cu}$ NPs were deposited on (i) $\mathrm{ZnO} / \mathrm{Al}_{2} \mathrm{O}_{3}$, (ii) $\mathrm{SiO}_{2}$, (iii) $\gamma-\mathrm{Al}_{2} \mathrm{O}_{3}$, and bimetallic $\mathrm{Cu}_{0.7} \mathrm{Zn}_{0.3} \mathrm{NPs}$ on (iv) $\mathrm{SiO}_{2}$, and (v) $\gamma-\mathrm{Al}_{2} \mathrm{O}_{3}$.

The NPs were prepared following an inverse micelle encapsulation method. Figure la shows an atomic force microscopy (AFM) image of the Cu NPs with a mean height of $3.1 \pm 0.8 \mathrm{~nm}$. Similar data were obtained for the $\mathrm{Cu}_{0.7} \mathrm{Zn}_{0.3}$ NPs (Supplementary Figure 1). A Cu/Zn ratio of $70 / 30$ was chosen for the bimetallic NPs to assure sufficient promotion of $\mathrm{Cu}$ by $\mathrm{Zn}^{4}$. The powder catalysts were synthesized by incipient wetness impregnation of the pre-formed NP solutions on the oxide supports (Supplementary Figure 2) and calcined at temperatures $\geq 400^{\circ} \mathrm{C}$ for $6 \mathrm{~h}$ in $20 \% \mathrm{O}_{2} /\left(\mathrm{Ar}\right.$ or $\mathrm{N}_{2}$ ) to completely remove the polymer. Figure $1 \mathrm{~b}$ shows a scanning transmission electron microscopy (STEM) image of the $\mathrm{CuZn} / \mathrm{SiO}_{2}$ catalyst. The mean particle size determined by TEM after calcination is $2.7 \pm 0.7 \mathrm{~nm}$. Energydispersive X-ray spectroscopy (EDX) maps in Fig. $1 \mathrm{c}$ and d confirm that the $\mathrm{Cu}$ and $\mathrm{Zn}$ signals, respectively, originate from the same NP. Figure 1e displays a STEM image of the $\mathrm{CuZn} / \mathrm{Al}_{2} \mathrm{O}_{3}$ sample showing isolated NPs. Figure if shows an EDX map overlayed with a high-angle annular dark-field image. The mean NP diameter determined by TEM is $3.3 \pm 0.7 \mathrm{~nm}$. In Fig. $1 \mathrm{~g}$ an EDX map for the $\mathrm{Cu} / \mathrm{ZnO} / \mathrm{Al}_{2} \mathrm{O}_{3}$ catalyst is displayed, showing $\mathrm{Cu}$ distributed over the $\mathrm{ZnO} / \mathrm{Al}_{2} \mathrm{O}_{3}$ support. Additional TEM images are shown in Supplementary Figures 3-5.

X-ray diffraction (XRD) patterns of the $\mathrm{Cu} / \mathrm{ZnO} / \mathrm{Al}_{2} \mathrm{O}_{3}$, $\mathrm{CuZn} / \mathrm{SiO}_{2}$, and $\mathrm{CuZn} / \mathrm{Al}_{2} \mathrm{O}_{3}$ catalysts were recorded in their calcined state and after reaction. A detailed description of the findings is included in the Supplementary Discussion, and Supplementary Figure 6. Note here that XRD is not sensitive to small atomically disordered NPs, and therefore, the results obtained are biased to the minority fraction of agglomerated NPs in these samples.

Catalyst structural evolution under a high-pressure environment. To gain insight into the interaction between $\mathrm{Cu}$ and $\mathrm{Zn}$ and into the evolution of their chemical state and structure under methanol synthesis conditions, the $\mathrm{Cu} / \mathrm{ZnO} / \mathrm{Al}_{2} \mathrm{O}_{3}, \mathrm{CuZn} / \mathrm{Al}_{2} \mathrm{O}_{3}$, and $\mathrm{CuZn} / \mathrm{SiO}_{2}$ catalysts were investigated by means of operando XAS at the $\mathrm{Cu}$ and $\mathrm{Zn}$ K-edges. The study of nano-sized pre-formed CuZn NPs allowed us to clearly track the evolution of the $\mathrm{Zn}$ species. This would be challenging to implement for the industrial catalyst as it contains $\mathrm{Zn}$ as the bulk support.

XAS data of the fresh calcined samples were acquired under $\mathrm{He}$ at room temperature, followed by a reduction (activation) under $10 \% \mathrm{H}_{2} / \mathrm{He}$ for $2 \mathrm{~h}$ at $245^{\circ} \mathrm{C}$ for the $\mathrm{Cu} / \mathrm{ZnO} / \mathrm{Al}_{2} \mathrm{O}_{3}$ and the $\mathrm{CuZn} / \mathrm{Al}_{2} \mathrm{O}_{3}$ catalysts and at $325^{\circ} \mathrm{C}$ for the $\mathrm{CuZn} / \mathrm{SiO}_{2}$ catalyst ${ }^{19}$. A higher reduction temperature was used for the NPs deposited on $\mathrm{SiO}_{2}$ owing to the higher stability of the $\mathrm{CuO}_{\mathrm{x}}$ species on this support. Further details on the effect of the reduction temperature are given in the Supplementary Discussion. Next, the samples were studied under an industrially relevant methanol synthesis mixture containing $4 \% \mathrm{CO}_{2}, 10 \% \mathrm{CO}, 72 \% \mathrm{H}_{2}$, balanced in $\mathrm{He}$, at: (i) 20 bar at $220^{\circ} \mathrm{C}$, (ii) 20 bar at $280^{\circ} \mathrm{C}$, (iii) 40 bar at $280{ }^{\circ} \mathrm{C}$, and (iv) $40 \mathrm{bar}$ at $320^{\circ} \mathrm{C}$. The last step at $320^{\circ} \mathrm{C}$ was performed in order to mimic an ageing treatment.

Figure 2 shows $\mathrm{Cu}$ K-edge and Zn K-edge X-ray absorption near-edge structure (XANES) data and Fig. 3 shows the magnitude of the Fourier transform (FT) of the extended X-ray absorption fine-structure (EXAFS) data of the three catalysts measured in their initial state and under the methanol synthesis mixture at 20 bar and $220^{\circ} \mathrm{C}$ (XAS data for the other reaction regimes are shown in Supplementary Figures 9-16). At the Cu Kedge, we observe that $\mathrm{Cu}$ species are initially oxidized and exhibit 

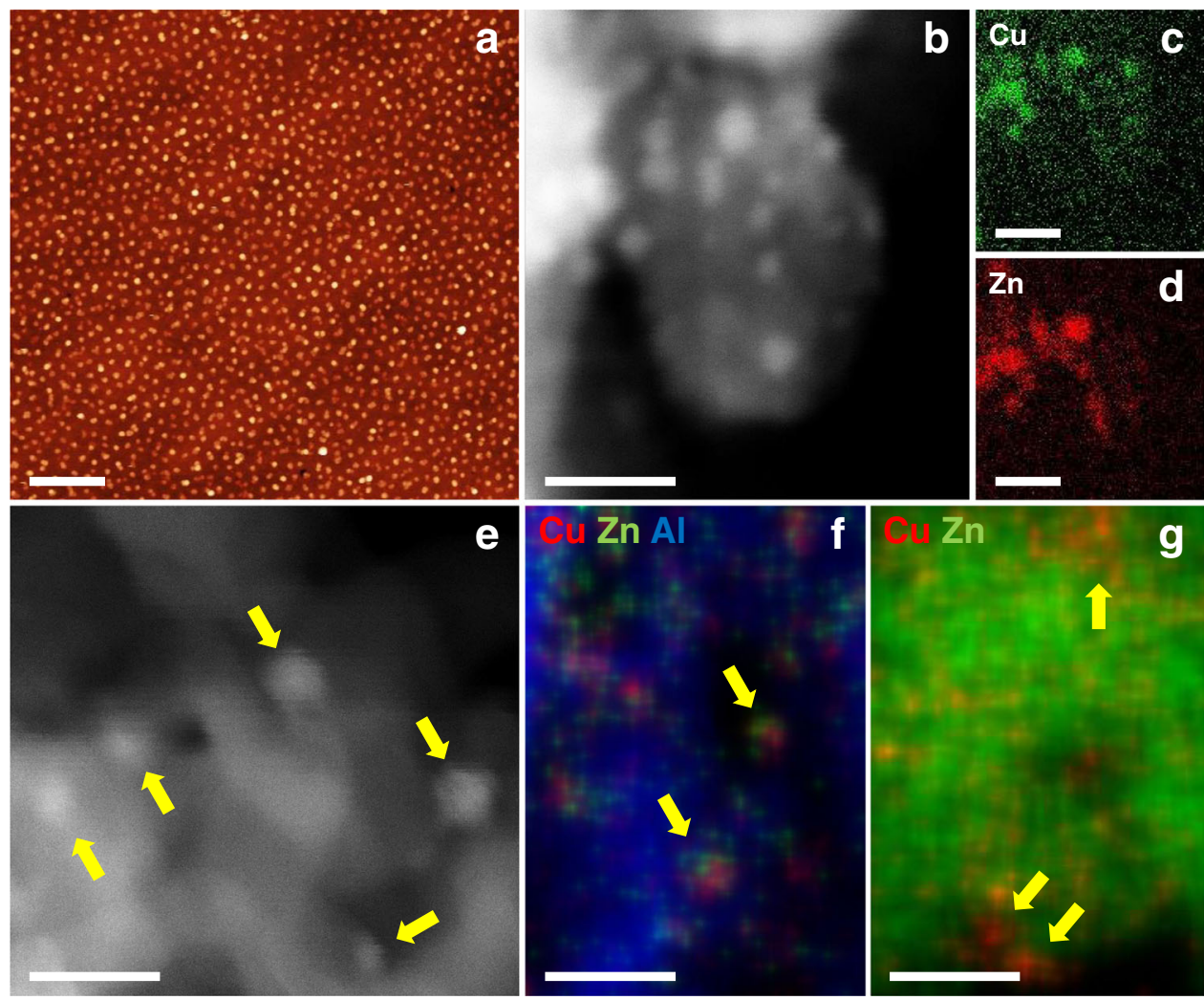

Fig. 1 Microscopy characterization of the catalysts. a AFM image of the $\mathrm{Cu} N \mathrm{NS}$ supported on $\mathrm{SiO}_{2} / \mathrm{Si}(111)$. b $\mathrm{STEM}$ image of the CuZn/SiO 2 catalyst; c, $\mathbf{d}$ show the corresponding $\mathrm{Cu}$ and $\mathrm{Zn}$ EDX maps. e STEM image and $\mathbf{f} E D X$ map of the $\mathrm{CuZn} / \mathrm{Al}_{2} \mathrm{O}_{3}$ catalyst. $\mathbf{g} \mathrm{EDX}$ map of the $\mathrm{Cu} / \mathrm{ZnO} / \mathrm{Al}{ }_{2} \mathrm{O}_{3}$ catalyst. In EDX maps $\mathbf{f}, \mathbf{g}$ red represents $\mathrm{Cu}$, green $\mathrm{Zn}$ and blue Al. The scale bars correspond to $\mathbf{a} 400 \mathrm{~nm}, \mathbf{b}-\mathbf{g} 10 \mathrm{~nm}$.
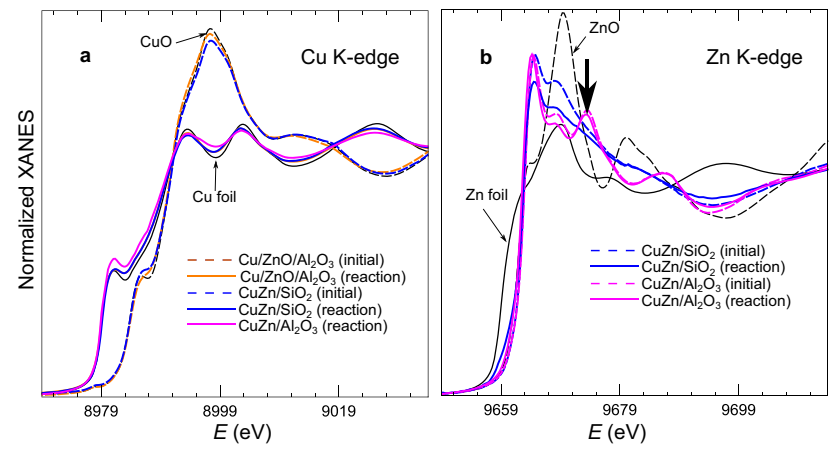

Fig. 2 Operando XANES spectra. a Cu K-edge and $\mathbf{b} \mathrm{Zn}$ K-edge XANES spectra for $\mathrm{Cu} / \mathrm{ZnO} / \mathrm{Al}_{2} \mathrm{O}_{3}, \mathrm{CuZn} / \mathrm{SiO}_{2}$ and $\mathrm{CuZn} / \mathrm{Al}_{2} \mathrm{O}_{3}$ catalysts in their initial state (dashed lines), and under operando conditions in $\mathrm{CO}_{2}+\mathrm{CO}+\mathrm{H}_{2}$, $p=20$ bar, $T=220^{\circ} \mathrm{C}$ (solid lines). The reference spectra for $\mathrm{CuO}$ and $\mathrm{ZnO}$ (dashed lines), $\mathrm{Cu}$ and $\mathrm{Zn}$ foils (solid lines) are also shown. The vertical arrow in $\mathbf{b}$ marks the signature of the zinc spinel structure.

a local structure similar to $\mathrm{CuO}$. Upon reduction in hydrogen and under reaction conditions, these species are reduced and remain reduced $\left(\mathrm{Cu}^{0}\right)$ (see Figs. 2a and 3a, Supplementary Figures 10 and 11 and Supplementary Table 8). EXAFS data (see Supplementary Discussion) indicate that, although some NP sintering was revealed by XRD and TEM (Supplementary Figures 3-6), the majority of $\mathrm{Cu}$ is available within well-dispersed NPs that remain stable during the reaction. This follows from the observation that the $1^{\text {st }}$ shell coordination numbers $(\mathrm{CNs})$ for reduced $\mathrm{Cu}$ are ca. $8-10$, in agreement with NP sizes of ca. $3 \mathrm{~nm}^{30}$. Importantly, no changes in the CNs were observed under the different reaction conditions, suggesting that the majority of particles retained their size, shape, and structure.

Notably, the Zn K-edge XAS data are substantially different for $\mathrm{CuZn} / \mathrm{SiO}_{2}$ and $\mathrm{CuZn} / \mathrm{Al}_{2} \mathrm{O}_{3}$, revealing the distinct interaction between the CuZn NPs and the silica and alumina supports. The $\mathrm{Zn} \mathrm{K}$-edge XANES spectra of $\mathrm{CuZn} / \mathrm{SiO}_{2}$ and $\mathrm{CuZn} / \mathrm{Al}_{2} \mathrm{O}_{3}$ catalysts in their initial state can be aligned well with the spectrum of wurtzite $\mathrm{ZnO}$ (where $\mathrm{Zn}$ is in $2+$ state and tetrahedrally coordinated), two main features appearing at 9664 $\mathrm{eV}$ and $9669 \mathrm{eV}$ in the $\mathrm{CuZn} / \mathrm{SiO}_{2}$ catalyst. Nevertheless, the relative intensities of these features are different for $\mathrm{CuZn} / \mathrm{SiO}_{2}$ and bulk $\mathrm{ZnO}$, and in conjunction with the weak contribution of distant coordination shells in the EXAFS data, indicate that $\mathrm{Zn}$ is present in a disordered oxide phase ${ }^{31}$. For the $\mathrm{CuZn} / \mathrm{Al}_{2} \mathrm{O}_{3}$ sample, the small peak in the Fourier-transformed $\mathrm{Zn}$ K-edge EXAFS spectra between 2.5 and $3.0 \AA$ is more pronounced and the $\mathrm{Zn}$ K-edge XANES spectra have an additional feature at ca. $9674 \mathrm{eV}$ (see arrow in Fig. 2b). Similar XANES fingerprints were previously observed for various spinel structures such as $\mathrm{ZnAl}_{2} \mathrm{O}_{4}{ }^{32}$, indicating the migration of $\mathrm{Zn}$ atoms into the alumina support.

Under operando conditions, only minor changes can be observed for the $\mathrm{Zn} \mathrm{K}$-edge XAS of $\mathrm{CuZn} / \mathrm{Al}_{2} \mathrm{O}_{3}$, suggesting the lack of significant reduction of the $\mathrm{Zn}$ species, which already incorporated in the $\mathrm{Al}_{2} \mathrm{O}_{3}$ matrix during the calcination. More pronounced changes are observed for the $\mathrm{CuZn} / \mathrm{SiO}_{2}$ : a decrease of the intensity of the main $\mathrm{Zn} \mathrm{K}$-edge XANES features and the appearance of a shoulder at the edge onset, characteristic for metallic $\mathrm{Zn}$ (Fig. 2b and Supplementary Figure 14). These changes can be related to the partial reduction of $\mathrm{Zn}$ species in this sample, and can be more easily observed in the $\mathrm{Zn}$ K-edge 

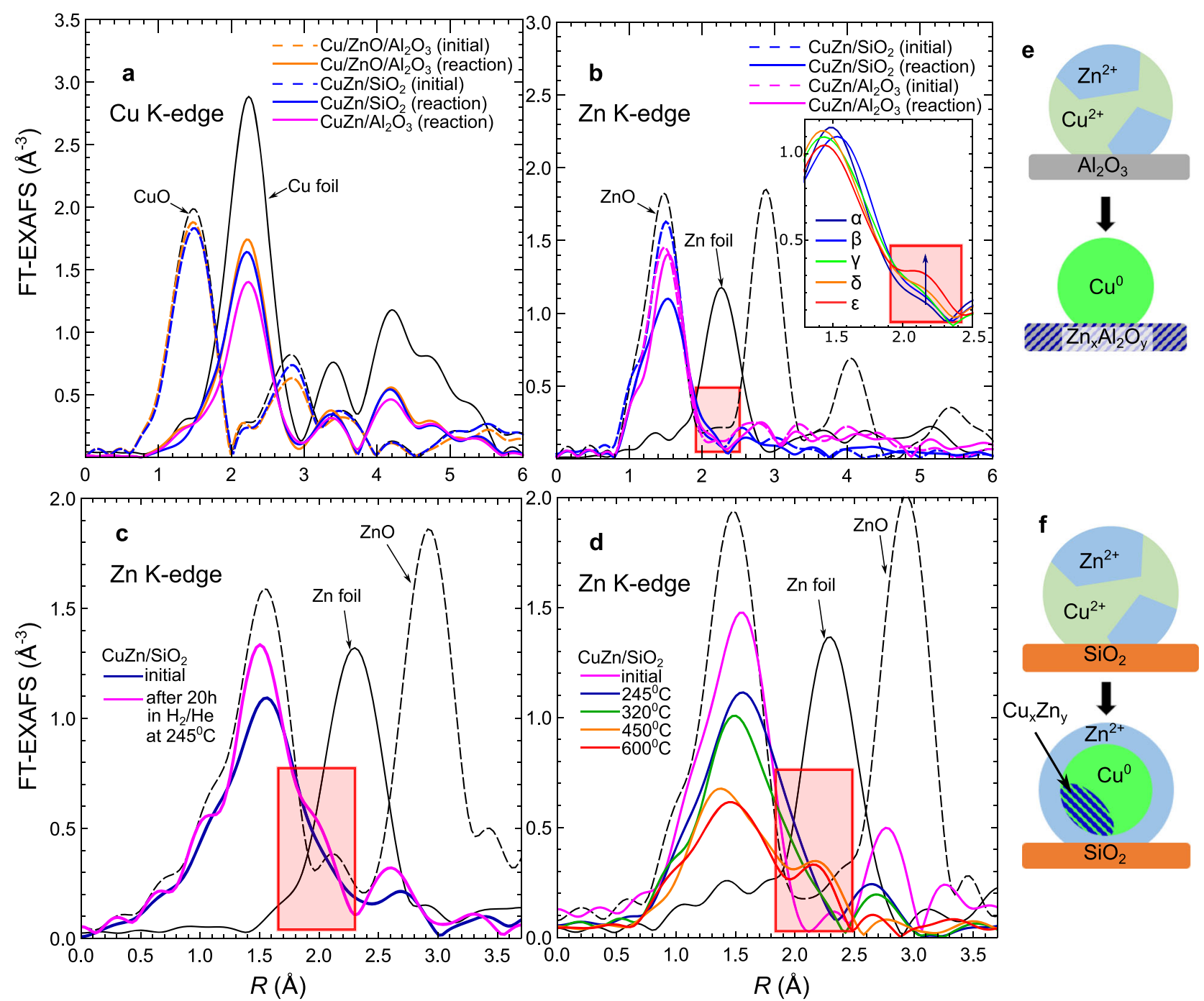

Fig. 3 Operando $\mathbf{C u}$ K-edge and Zn K-edge EXAFS spectra. The FT magnitude of the a $\mathrm{Cu}$ K-edge and $\mathbf{b} \mathrm{Zn} \mathrm{K}$-edge EXAFS spectra for $\mathrm{Cu} / \mathrm{ZnO} / \mathrm{Al}{ }_{2} \mathrm{O}_{3}$, $\mathrm{CuZn} / \mathrm{SiO}_{2}$, and $\mathrm{CuZn} / \mathrm{Al}_{2} \mathrm{O}_{3}$ catalysts in their initial state (dashed lines), and under operando conditions in $\mathrm{CO}_{2}+\mathrm{CO}^{\circ} \mathrm{H}_{2}, p=20$ bar, $T=220^{\circ} \mathrm{C}$ (solid lines). The magnitude of the FT of the EXAFS spectra for $\mathrm{CuZn} / \mathrm{SiO}_{2}$ during $\mathbf{c}$ a reduction in $10 \% \mathrm{H}_{2} / \mathrm{He}$ for $20 \mathrm{~h}$ at $245^{\circ} \mathrm{C}$ and $\mathbf{d}$ at temperatures between 245 and $600^{\circ} \mathrm{C}$. The reference spectra for a $\mathrm{Zn}$ foil, $\mathrm{ZnO}, \mathrm{CuO}$, and $\mathrm{Cu}$ foil are also shown. The highlighted areas in $\mathbf{b}$-d indicate the region where the $\mathrm{Zn}-\mathrm{M}$ bond develops under reaction conditions. The latter is also shown in the inset in $\mathbf{b}$, with spectra $\alpha, \beta, \gamma, \delta$, and $\varepsilon$ corresponding to consequent measurements at $220^{\circ} \mathrm{C} / 20$ bar, $280^{\circ} \mathrm{C} / 20$ bar, $280^{\circ} \mathrm{C} / 40$ bar, and $320^{\circ} \mathrm{C} / 40$ bar. To enhance the display of the referred features, different $\mathrm{k}$-ranges were used for the Fourier transform in $\mathbf{a}, \mathbf{b} 1-10.5 \AA^{-1}, \mathbf{c} 3-12 \AA^{-1}$, and $\mathbf{d} 1-10 \AA^{-1}$. The observed changes are schematically presented in $\mathbf{e}$ for $\mathrm{CuZn}_{\mathrm{Z}} \mathrm{Al}_{2} \mathrm{O}_{3}$ and f for $\mathrm{CuZn} / \mathrm{SiO}_{2}$.

EXAFS spectra (Fig. 3b and Supplementary Figure 16), where an additional feature appears at ca. $2.2 \AA$ in the FT and systematically increases under reaction conditions. This feature can be linked to the formation of $\mathrm{Zn}-\mathrm{Zn}$ or $\mathrm{Zn}-\mathrm{Cu}$ bonds and its intensity is low after a $2 \mathrm{~h}$ reduction at $325^{\circ} \mathrm{C}$ (or during the first measurements under operando conditions), but becomes more pronounced with increasing reaction time. To confirm that the development of this feature was related to the prolonged exposure to reducing conditions, we investigated the effect of reducing atmospheres at different temperatures on the reduction of $\mathrm{Zn}$. We collected the $\mathrm{Zn}$ K-edge XAS data for $\mathrm{CuZn} / \mathrm{SiO}_{2}$ after $20 \mathrm{~h}$ under $10 \% \mathrm{H}_{2} / \mathrm{He}$ at $245^{\circ} \mathrm{C}$ and 1 bar (Fig. $3 \mathrm{c}$ and Supplementary Figure 17), and observed similar changes: the peak at ca. $2.2 \AA$ related to $\mathrm{Zn}-\mathrm{M}$ bonds clearly develops. This long-term study thus shows an increasing metallic $\mathrm{Zn}$ contribution for the $\mathrm{CuZn} /$ $\mathrm{SiO}_{2} \mathrm{NPs}$ after the $20 \mathrm{~h}$, as compared with that after $1-2 \mathrm{~h}$ of the reduction (Fig. 3d), indicating slowly progressing reduction of $\mathrm{Zn}$ species. To further corroborate this finding, we performed an additional experiment where the $\mathrm{CuZn} / \mathrm{SiO}_{2}$ sample was investigated under $10 \% \mathrm{H}_{2} / \mathrm{He}$ at 1 bar and temperatures from $245^{\circ} \mathrm{C}$ up to $600{ }^{\circ} \mathrm{C}$ (Fig. $3 \mathrm{~d}$ and Supplementary Figure 17). EXAFS data fitting (Supplementary Figures 12, 13, and 18, and Supplementary Table 9) confirmed the gradual transformation of initially tetrahedrally coordinated oxidized $\mathrm{Zn}$ species into a material with coexisting $\mathrm{ZnO}$ and reduced $\mathrm{Zn}$ species.

Surface reorganization and oxidation state evolution. To complement the bulk chemical and structural information obtained by XAS and gain further insight on the outermost layers of the NPs, synchrotron near-ambient pressure X-ray photoelectron spectroscopy (NAP-XPS) measurements were carried out. With this method, further knowledge was attained on the evolution of the oxidation state and surface composition of $6 \mathrm{~nm}$ $\mathrm{Cu}_{0.7} \mathrm{Zn}_{0.3}$ NPs deposited on $\mathrm{SiO}_{2} / \mathrm{Si}(100)$ (Fig. 4 and Supplementary Figure 19). In particular, depth profile information of the 

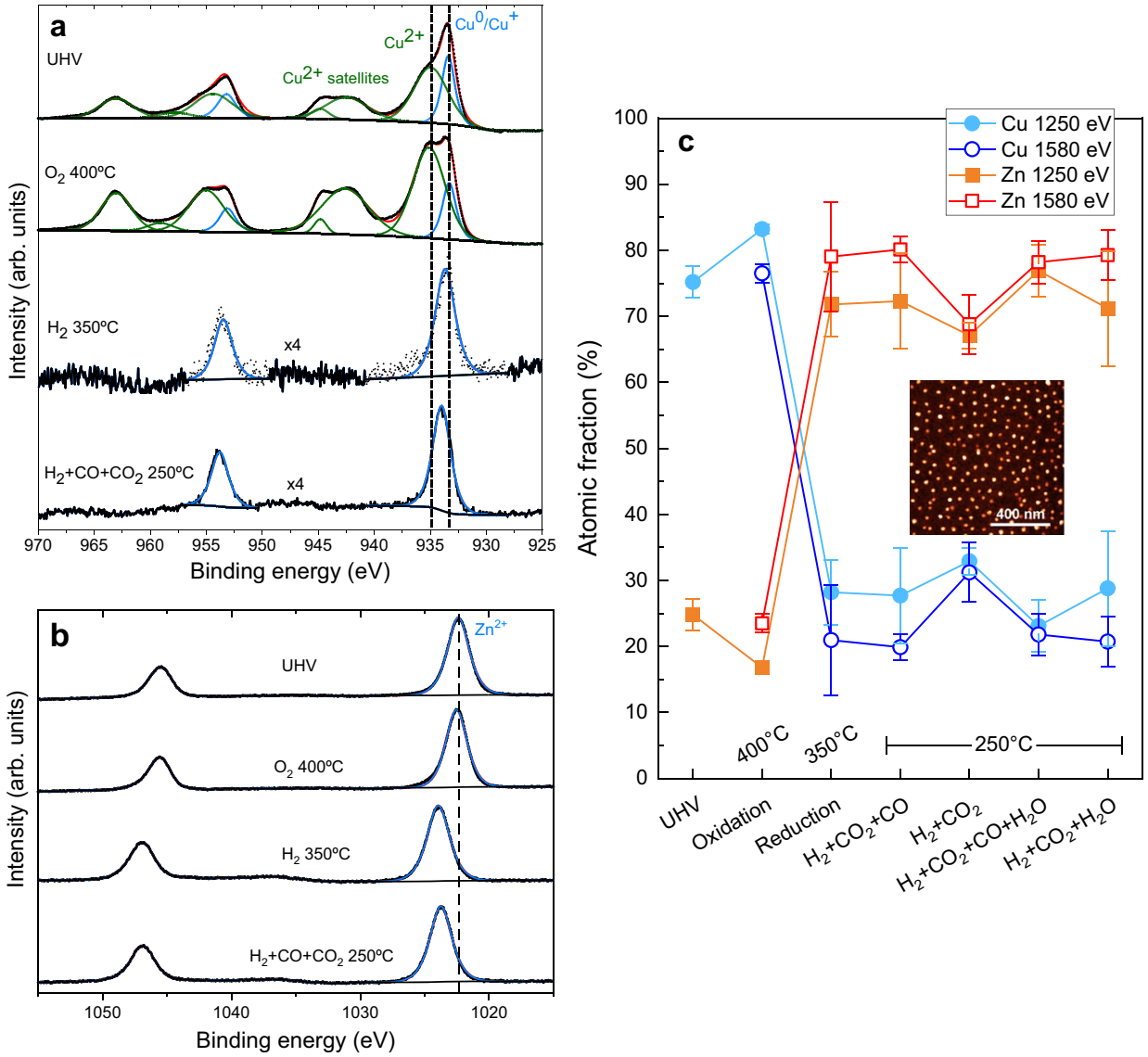

Fig. 4 Near-ambient pressure X-ray photoelectron spectra of $\mathbf{C u Z n ~ N P s}$ on $\mathbf{S i O}_{\mathbf{2}} / \mathbf{S i ( 1 0 0 )}$ ) a $\mathrm{Cu} 2 p$ and $\mathbf{b} \mathrm{Zn} 2 p$ regions recorded using a photon energy of $1250 \mathrm{eV}$. c Copper and zinc atomic fractions obtained under different atmospheres as indicated on the plot. The two-photon energies used for probing the surface $(1250 \mathrm{eV})$ and subsurface $(1580 \mathrm{eV})$ regions of the CuZn NPs are displayed. Error bars correspond to the standard deviation. The inset shows an AFM image of the sample.

NP composition was obtained by choosing two different incident photon energies: $1250 \mathrm{eV}$, corresponding to inelastic mean free paths (IMFP) of $\sim 0.8 \mathrm{~nm}$ for $\mathrm{Cu} 2 p$ and $0.7 \mathrm{~nm}$ for $\mathrm{Zn} 2 p$ photoelectrons, and $1580 \mathrm{eV}$ corresponding to $\sim 1.2 \mathrm{~nm}$ IMFP for $\mathrm{Cu}$ $2 p$ and $\mathrm{Zn} 2 p^{33}$. The series of in situ NAP-XPS data consisted of: (i) oxidation at $400^{\circ} \mathrm{C}$ in $0.13 \mathrm{mbar} \mathrm{O}_{2}$ to remove adventitious carbon, (ii) reduction at $350{ }^{\circ} \mathrm{C}$ in $1.3 \mathrm{mbar} \mathrm{H}_{2}$, and (iii) reaction at $250{ }^{\circ} \mathrm{C}$ in $1.3 \mathrm{mbar}$ of the reaction gas mixture. The effects of different reaction mixtures $\left(\mathrm{CO}_{2}+\mathrm{CO}+\mathrm{H}_{2}\right.$ versus $\left.\mathrm{CO}_{2}+\mathrm{H}_{2}\right)$ and the presence of water ${ }^{34}$ on the surface reorganization and chemical state of different species present during the reaction were studied (see concentrations in Supplementary Table 7).

The series of $\mathrm{Cu} 2 p_{3 / 2}$ and $\mathrm{Zn} 2 p_{3 / 2}$ NAP-XPS spectra, as well as the $\mathrm{X}$-ray generated $\mathrm{Cu}$ and $\mathrm{Zn}$ LMM Auger regions are shown in Figs. 4a, b and Supplementary Figures 20-23. In the initial state under ultra-high vacuum (UHV) conditions, the $\mathrm{Cu}$ and $\mathrm{Zn}$ atomic ratios are 75:25, close to the nominal 70:30 synthesis ratio. $\mathrm{Cu} 2 p$ shows the typical satellites of $\mathrm{Cu}^{2+35}$, but can only be adequately fitted with an additional component of $\mathrm{Cu}^{+}$or $\mathrm{Cu}^{0}$ (ca. 25\%); $\mathrm{Zn} 2 p$ indicates the presence of $\mathrm{ZnO}$. During the initial treatment in $\mathrm{O}_{2}$ at $400{ }^{\circ} \mathrm{C}$, copper gets almost fully oxidized and the $\mathrm{Cu} / \mathrm{Zn}$ ratio at the surface increases slightly, indicating a slight $\mathrm{Cu}$ surface segregation (Fig. 4c). The deconvolution of the $\mathrm{Zn}$ Auger region shows that zinc is present as $\mathrm{ZnO}$ (Supplementary Figure 22). Upon exposure to $\mathrm{H}_{2}$ at $350{ }^{\circ} \mathrm{C}$, strong segregation of $\mathrm{Zn}$ toward the surface and of $\mathrm{Cu}$ toward the core of the NPs is observed, indicating the formation of a Zn-rich overlayer on the NPs. The Zn atomic content at the surface reached $\sim 72 \%$. This is in agreement with previous reports ${ }^{1,36}$ and responds to the higher stability of $\mathrm{ZnO}$ as compared with $\mathrm{CuO}$ in a reductive atmosphere. A shift toward higher binding energies (BEs) of the $\mathrm{Zn} 2 p$ and $\mathrm{Cu} 2 p$ and the Auger regions was observed, which can be due to charging effects of the $\mathrm{SiO}_{2}$ substrate. Under $\mathrm{H}_{2}$ atmosphere, copper gets fully reduced, which can be confirmed by the $\mathrm{Cu}$ LMM Auger spectrum (Supplementary Figure 23$)^{35}$. At the same time, the shift of the $\mathrm{Zn} 2 p$ region towards higher BEs indicates that $\mathrm{Zn}$ mainly remains in $\mathrm{Zn}^{2+}$ state, either in the form of $\mathrm{ZnO}$ or $\mathrm{Zn}(\mathrm{OH})_{2}$. Analysis of the $\mathrm{Zn}$ LMM region, which is more sensitive to the $\mathrm{Zn}$ oxidation state, suggests a maximum of 5\% metallic $\mathrm{Zn}$ coexisting with $\mathrm{ZnO}$. It has been previously reported that the $\mathrm{ZnO}$ overlayer formed corresponds to distorted $\mathrm{ZnO}^{11,37}$, which is also in good agreement with our in situ XAS results.

Under reaction conditions at $250^{\circ} \mathrm{C}$ with the $\mathrm{H}_{2}+\mathrm{CO}+\mathrm{CO}_{2}$ mixture (as used before), no further reorganization of the metals is observed. $\mathrm{Cu}$ remains reduced and the $\mathrm{Zn}$ LMM lines seem to indicate a slight increase (up to 9\%) in the concentration of metallic $\mathrm{Zn}$. This indicates that under methanol synthesis conditions, the surface of the NPs remains Zn-rich, with a distorted $\mathrm{ZnO}_{\mathrm{x}}$ layer located on top of the $\mathrm{Cu}$ NPs. Interestingly, this applies to the water-containing mixtures as well. Only under $\mathrm{H}_{2}+\mathrm{CO}_{2}$, a slight $\mathrm{Cu}$ surface segregation is observed, reaching 33 at. $\% \mathrm{Cu}$ at the surface.

To bridge the pressure gap and display the relevance of these surface-sensitive experiments for the high-pressure regime, quasi in situ XPS measurements in combination with a high-pressure 

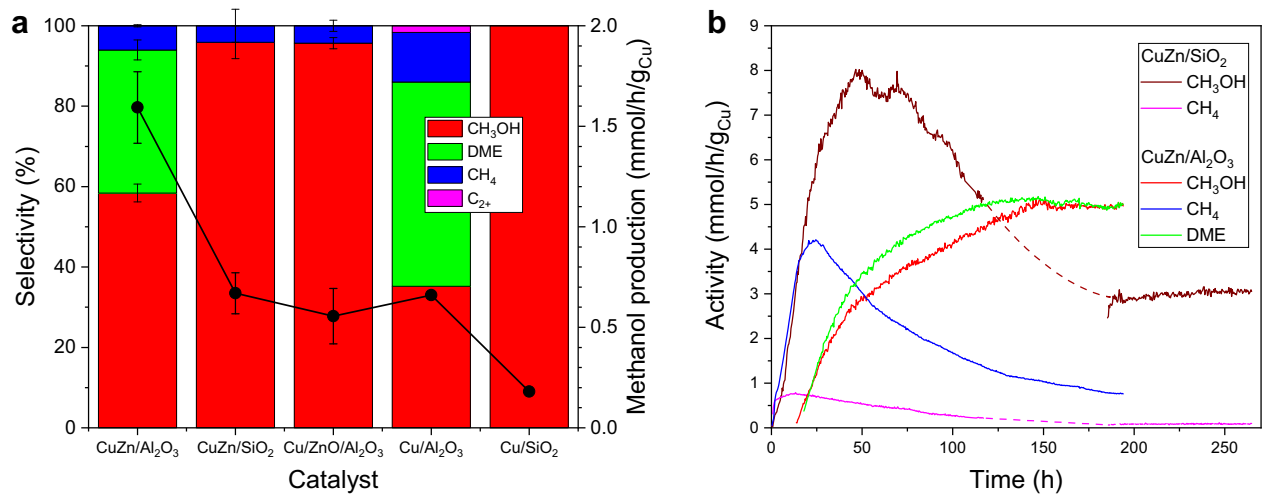

Fig. 5 Catalytic performance and evolution of the reaction products during the activation. a Comparison of the methanol production and overall selectivity of all catalysts at $250^{\circ} \mathrm{C}$ and 40 bar. The $\mathrm{C}_{2+}$ products are mainly $\mathrm{C}_{2} \mathrm{H}_{6}$. Error bars represent standard deviation. $\mathbf{b}$ Temporal evolution of the main reaction products of the $\mathrm{CuZn} / \mathrm{SiO}_{2}$ and $\mathrm{CuZn} / \mathrm{Al}_{2} \mathrm{O}_{3}$ catalysts at 40 bar and $280^{\circ} \mathrm{C}$ during an activation treatment until the steady state was achieved. The dashed lines serve as a guide for the eye.

reactor cell (HPC) were carried out (Supplementary Figure 25). For this purpose, the same experimental conditions as for the synchrotron-based operando NAP-XPS measurements were applied in the HPC, but at more relevant pressures ( 1 bar for the reduction and $20 \mathrm{bar}$ in the reaction mixture), before measuring the sample with XPS in UHV. A detailed description of these experiments can be found in the Supplementary Discussion. It is shown that there is no pressure effect for the segregation trends of these samples and therefore, our NAP-XPS synchrotron results stay valid even at higher pressures.

Catalytic performance. The activity of the catalysts in powder form was tested in a fixed-bed reactor at 20,40 , and $60 \mathrm{bar}$, at temperatures from $220^{\circ} \mathrm{C}$ to $280^{\circ} \mathrm{C}$ (later described as "reaction cycle") in a reactant mixture of $\mathrm{CO}_{2} / \mathrm{CO} / \mathrm{H}_{2} / \mathrm{He}=4 / 10 / 74 / 12$, with a weight-to-flow ratio $\mathrm{W} / \mathrm{F}=0.18 \mathrm{~g} \mathrm{~s} / \mathrm{mL}$. Figure $5 \mathrm{a}$ and Supplementary Figure 7 display the steady-state reactivity data of our catalysts at different temperatures and pressures after an activation pre-treatment.

As shown in Fig. 5a, under steady-state operation and regardless of the support, the bimetallic CuZn NPs produce always more methanol than their monometallic $\mathrm{Cu}$ counterparts. The highest methanol yield was obtained for $\mathrm{CuZn} / \mathrm{Al}_{2} \mathrm{O}_{3}$, followed by $\mathrm{CuZn} / \mathrm{SiO}_{2}, \mathrm{Cu} / \mathrm{ZnO} / \mathrm{Al}_{2} \mathrm{O}_{3}$, and $\mathrm{Cu} / \mathrm{Al}_{2} \mathrm{O}_{3}$, and a lower rate was observed for $\mathrm{Cu} / \mathrm{SiO}_{2}$. Interestingly, $\mathrm{CuZn} / \mathrm{SiO}_{2}$ is significantly less active than $\mathrm{CuZn} / \mathrm{Al}_{2} \mathrm{O}_{3}$, but comparable in activity to $\mathrm{Cu} / \mathrm{ZnO} / \mathrm{Al}_{2} \mathrm{O}_{3}$. In addition, the stabilization of the methanol production for the $\mathrm{CuZn} / \mathrm{SiO}_{2}$ catalyst took longer, and a significant deactivation after an initial increase of the methanol production was observed. The temporal evolution of the methanol production of the $\mathrm{CuZn} / \mathrm{SiO}_{2}$ and $\mathrm{CuZn} / \mathrm{Al}_{2} \mathrm{O}_{3}$ samples (at $40 \mathrm{bar}$ and $280^{\circ} \mathrm{C}$ ) for $250 \mathrm{~h}$ is displayed in Fig. $5 \mathrm{~b}$, featuring the deactivation of $\mathrm{CuZn} / \mathrm{SiO}_{2}$ until the steady-state was achieved. Considering the selectivity trends, we observe that our mostactive catalyst $\left(\mathrm{CuZn} / \mathrm{Al}_{2} \mathrm{O}_{3}\right)$ is the least selective for methanol (selectivity towards methanol is ca. $58 \%$, at $250^{\circ} \mathrm{C}, 40$ bar) with significant production of dimethylether (DME) at the highest reaction temperatures $\left(250^{\circ} \mathrm{C}, 280^{\circ} \mathrm{C}\right)$ and to a lesser extent of $\mathrm{CH}_{4}$, as shown in Fig. 5a and Supplementary Figure 7. This is due to the presence of the acidic sites of $\gamma-\mathrm{Al}_{2} \mathrm{O}_{3}$, which are able to further catalyze the dehydration of the produced methanol to $\mathrm{DME}^{38,39}$. Its monometallic counterpart, the $\mathrm{Cu} / \mathrm{Al}_{2} \mathrm{O}_{3}$ catalyst, shows higher DME and $\mathrm{CH}_{4}$ selectivity, at the expense of methanol, and the minor (1\%) production of longer hydrocarbons, such as $\mathrm{C}_{2} \mathrm{H}_{6}$. On the other hand, the silica- and $\mathrm{ZnO} /$ $\mathrm{Al}_{2} \mathrm{O}_{3}$-supported catalysts are highly selective toward methanol.
Owing to the low amount of $\mathrm{Cu}$ and $\mathrm{Zn}$ with respect to the amount of the support material in our samples $(<5 \mathrm{wt} . \%$ total concentration), the contribution from the support is more significant for our catalysts as compared with the industrial bulk-like samples (see the methods section for details).

\section{Discussion}

Our XAS data acquired at relevant industrial pressures allow the pressure effect on the local structure of the $\mathrm{CuZn} / \mathrm{SiO}_{2}$ catalyst to be determined. By comparing the results obtained during the activation under hydrogen ( 1 bar) and reaction steps at 20 and 40 bar, both from the XANES and EXAFS data analyses (Supplementary Figures 9 and 11 and Supplementary Table 8), it can be seen that the $\mathrm{Cu}$ structural parameters for the activation step (1 bar, $325^{\circ} \mathrm{C}$ ) are similar to those obtained under the methanol synthesis mixture at the highest temperature studied ( $40 \mathrm{bar}, 320$ ${ }^{\circ} \mathrm{C}$, step that corresponds to the ageing treatment performed). Therefore, we conclude that no significant pressure or chemical potential effect can be detected on the $\mathrm{Cu}$ local structure for the $\mathrm{CuZn} / \mathrm{SiO}_{2}$ catalyst. Combining these XAS results with the XRD data of the catalysts after reaction (these techniques are sensitive to short and long-range order, respectively), the majority of copper remains stable (XAS) but a small fraction of the NPs sinter (XRD and TEM). It is worth mentioning here that the after reaction TEM and XRD data were recorded after more than $150 \mathrm{~h}$ under operation, including steps at $280^{\circ} \mathrm{C}$, which could favor the aggregation of $\mathrm{Cu}$. In addition, the XRD data also confirmed the formation of the $\mathrm{CuZn}$ phase on $\mathrm{SiO}_{2}$ after reaction (see Supplementary Figure 6 and Supplementary Discussion).

The temporal evolution of the catalytic performance displayed in Fig. $5 b$, where the $\mathrm{CuZn} / \mathrm{SiO}_{2}$ gradually deactivates until it reaches the steady state after ca. $200 \mathrm{~h}$ under operation, can be linked to the gradual reduction of $\mathrm{ZnO}$ under operando conditions, as inferred from XAS and corroborated by NAP-XPS. As stated earlier, from the spectroscopic results under methanol synthesis conditions we observe the partial reduction of $\mathrm{ZnO}$, leading to the coexistence of $\mathrm{ZnO}$ with reduced $\mathrm{Zn}$ species. Furthermore, from the NAP-XPS results, we can conclude that $\mathrm{ZnO}$ and reduced $\mathrm{Zn}$ species are mostly located at the surface of our CuZn NPs. By XAS, we observe a similar evolution of $\mathrm{Zn}$ after 20 $h$ under $10 \% \mathrm{H}_{2} / \mathrm{He}$ at $245^{\circ} \mathrm{C}$ and 1 bar pressure (Fig. 3c). Thus, we can conclude that the partial reduction of $\mathrm{ZnO}$ and formation of either metallic $\mathrm{Zn}$ or $\mathrm{Zn}-\mathrm{Cu}$ bonds are not dependent on the pressure or the specific composition of the reducing reaction $\left(\mathrm{H}_{2}\right.$ versus $\mathrm{CO}_{2}+\mathrm{CO}+\mathrm{H}_{2}$ ) mixture. $\mathrm{Zn}$ reduction is, however, significantly enhanced at higher temperatures $\left(>250^{\circ} \mathrm{C}\right)$. The 
temperature effect is also demonstrated in the aging experiment performed under $10 \% \mathrm{H}_{2} / \mathrm{He}$ at 1 bar pressure and $245^{\circ} \mathrm{C}, 320^{\circ} \mathrm{C}$, $450^{\circ} \mathrm{C}$, and $600{ }^{\circ} \mathrm{C}$ (Fig. $3 \mathrm{~d}$ and Supplementary Figure 17), where the contribution of the $\mathrm{Zn}-\mathrm{M}$ feature is low at $320^{\circ} \mathrm{C}$, but is increasingly more pronounced at $450{ }^{\circ} \mathrm{C}$ and $600^{\circ} \mathrm{C}$, demonstrating and emphasizing the temperature effect on the reducibility of the $\mathrm{Zn}$ species. The unambiguous attribution of the latter species to metallic $\mathrm{Zn}$ or $\mathrm{CuZn}$ alloy formation is not possible owing to their relatively low contribution to our XAS data, together with the similar scattering cross-sections of $\mathrm{Cu}$ and $\mathrm{Zn}$, making them indistinguishable by XAS. However, the EXAFS $\mathrm{Zn}-\mathrm{M}$ bond length is similar to the $\mathrm{Cu}-\mathrm{Cu}$ bond length in metallic $\mathrm{Cu}$, thus, the incorporation of $\mathrm{Zn}$ into a $\mathrm{Cu}$-rich alloy is a viable hypothesis. Note that the formation of CuZn alloy (brass) in $\mathrm{CuZn}$ catalysts was previously reported under $\mathrm{CO} / \mathrm{H}_{2}$ atmosphere at $600{ }^{\circ} \mathrm{C}^{17}$, and other references also suggested that some alloying of $\mathrm{Cu}$ and $\mathrm{Zn}$ can take place at temperatures as low as $250^{\circ} \mathrm{C}^{26}$. Our results confirm that this process also takes place at lower temperatures, namely $245^{\circ} \mathrm{C}$, although then the rate of $\mathrm{ZnO}$ reduction is slower.

Regarding the catalytic activity, higher intrinsic methanol formation rates have been reported for $\mathrm{Cu} / \mathrm{Al}_{2} \mathrm{O}_{3}$ than for $\mathrm{Cu} /$ $\mathrm{SiO}_{2}{ }^{39}$, which is in agreement with our data and has been attributed to the Lewis acid nature of the $\mathrm{Al}_{2} \mathrm{O}_{3}$ support. Nevertheless, the presence of the stronger acid sites of $\gamma-\mathrm{Al}_{2} \mathrm{O}_{3}$ leads to the dehydration of methanol to DME. From our data, we observe that the addition of $\mathrm{Zn}$ promotes the methanol formation for both, the $\mathrm{CuZn} / \mathrm{Al}_{2} \mathrm{O}_{3}$ and the $\mathrm{CuZn} / \mathrm{SiO}_{2}$ catalysts and its selectivity in the case of $\mathrm{CuZn} / \mathrm{Al}_{2} \mathrm{O}_{3}$ versus $\mathrm{Cu} / \mathrm{Al}_{2} \mathrm{O}_{3}$. This is remarkable and highlights the importance of the intimate $\mathrm{CuZn}$ interaction for the $\mathrm{CO}_{2}+\mathrm{CO}$ hydrogenation reaction, since in our catalysts zinc is not present as a bulk support, as done in previous studies, but as a highly diluted phase forming the CuZn NPs. For $\mathrm{CuZn} / \mathrm{SiO}_{2}$, the addition of $\mathrm{Zn}$ causes a methanol production rate increase ca. three times with respect to its monometallic counterpart, and a similar increase is also obtained for $\mathrm{CuZn} / \mathrm{Al}_{2} \mathrm{O}_{3}$. It is interesting to note here that the $\mathrm{Zn} \mathrm{K}$-edge XAS data revealed for the $\mathrm{CuZn} / \mathrm{Al}_{2} \mathrm{O}_{3}$ catalyst the migration of $\mathrm{Zn}$ atoms to the alumina support and the lack of significant $\mathrm{Zn}$ reduction. Nevertheless, our data clearly show that $\mathrm{Zn}$ is still able to promote the methanol formation rate and improve its selectivity from $35 \%$ for $\mathrm{Cu} / \mathrm{Al}_{2} \mathrm{O}_{3}$ to $58 \%$ for $\mathrm{CuZn} / \mathrm{Al}_{2} \mathrm{O}_{3}$. By comparing the methanol yields of our NPs with those of the bulk-like industrial $\mathrm{Cu} / \mathrm{ZnO} / \mathrm{Al}_{2} \mathrm{O}_{3}$ catalyst reference measured under identical conditions (Supplementary Figure 8), a clear size-effect is observed, with a lower methanol production for the 2-3 nm NPs employed here, as previously reported elsewhere ${ }^{4}$. This result highlights that operating with the highest possible surface area materials (smallest NPs $<5 \mathrm{~nm}$ ) is not always beneficial for the catalytic process. In addition, the lower $\mathrm{Cu}$ and $\mathrm{Zn}$ concentrations used in our study ( $<5$ wt.\% total metal loading) could also lead to lower methanol productions than those obtained with the industrial catalyst ${ }^{40}$.

We finally conclude that morphologically, structurally, and chemically well-defined catalysts composed of ca. $3 \mathrm{~nm} \mathrm{Cu}$ and $\mathrm{CuZn}$ NPs supported on $\mathrm{ZnO} / \mathrm{Al}_{2} \mathrm{O}_{3}, \gamma-\mathrm{Al}_{2} \mathrm{O}_{3}$, and $\mathrm{SiO}_{2}$ were synthesized in order to investigate $\mathrm{CuZn}$ and NP/support interactions. By using operando XAS data acquired at high pressure (up to 40 bar), we were able to follow the evolution of the NPs' structure and composition under reaction conditions. For both, $\mathrm{CuZn} / \mathrm{SiO}_{2}$ and $\mathrm{CuZn} / \mathrm{Al}_{2} \mathrm{O}_{3}$, the majority of the zinc species are present in the form of a disordered oxide, whose structure depends strongly on the support. In particular, the incorporation of $\mathrm{Zn}$ in the $\mathrm{Al}_{2} \mathrm{O}_{3}$ support was observed for $\mathrm{CuZn} / \mathrm{Al}_{2} \mathrm{O}_{3}$, forming a spinel-like structure that hinders the reduction of the cationic $\mathrm{Zn}$ species under reaction conditions. On the other hand, for $\mathrm{CuZn} / \mathrm{SiO}_{2}$, we observed the gradual reduction of the oxidic zinc species under reaction conditions, and the formation of $\mathrm{Zn}-\mathrm{Cu}$ or $\mathrm{Zn}-\mathrm{Zn}$ bonds. Although this reduction is accelerated at higher temperatures, it was already observed at temperatures commonly used for methanol production (i.e., $250^{\circ} \mathrm{C}$ ). The slow reduction of $\mathrm{ZnO}$ species in this sample observed by XAS is paralleled by a decrease in methanol yield as a function of the reaction time. After an initial deactivation, the steady-state methanol production of $\mathrm{CuZn} / \mathrm{SiO}_{2}$ is still similar to that of $\mathrm{Cu} /$ $\mathrm{ZnO} / \mathrm{Al}_{2} \mathrm{O}_{3}$, but $\mathrm{CuZn} / \mathrm{SiO}_{2}$ is far more active than $\mathrm{Cu} / \mathrm{SiO}_{2}$. This indicates the beneficial effect of the $\mathrm{CuZn}$ interaction even if the $\mathrm{ZnO}$ species get partially reduced or if they are present highly diluted as part of the NPs. In addition, NAP-XPS data revealed $\mathrm{Zn}$ surface segregation for $\mathrm{CuZn} / \mathrm{SiO}_{2}$, and the formation of a distorted $\mathrm{ZnO}_{\mathrm{x}}$ overlayer, virtually independent from the chosen reactant mixture. Our data indicate that a strong interaction of $\mathrm{Cu}$ and $\mathrm{ZnO}$ is necessary for a highly selective and active catalyst, which is affected by the choice of the support and the nature of the CuZn interface.

\section{Methods}

Synthesis of powder catalysts. The size-controlled NPs were synthesized by an inverse micelle encapsulation method. Monodisperse micellar NP solutions were prepared by dissolving [poly(styrene)-block-poly-(2-vinylpyridine), PS-P2VP, Polymer Source Inc.] polymers in toluene and stirred for 2 days. In parallel, the metal salts $\mathrm{CuCl}_{2} \cdot 2 \mathrm{H}_{2} \mathrm{O}$ (Sigma Aldrich), $\mathrm{ZnCl}_{2}$ (Alfa Aesar), or $\mathrm{Zn}(\mathrm{OAc})_{2}$ (Sigma Aldrich) were dispersed in tetrahydrofuran and stirred for 2 days. Nominal $\mathrm{Cu}$ : $\mathrm{Zn}=70: 30$ atomic ratios were used. Subsequently, the solutions containing the metal salts were incorporated into the micellar solutions and stirred for 2 additional days. The PS-P2VP molecular weights and the polymer-head (P2VP)-tometal salt ratios are reported in Supplementary Table 1.

The NP height was determined via AFM (Bruker MultiMode 8 microscope) on dip-coated $\mathrm{SiO}_{2} / \mathrm{Si}(111)$ wafers after polymer removal by oxygen plasma $(0.3 \mathrm{mbar})$ (Fig. 1a and Supplementary Figure 1).

The $\mathrm{Cu}$ and $\mathrm{Cu}_{0.7} \mathrm{Zn}_{0.3}$ NPs were supported on nanocrystalline powders via incipient wetness impregnation of the NP solutions. The supports employed are commercial $\mathrm{SiO}_{2}$ (STREM chemicals), $\gamma-\mathrm{Al}_{2} \mathrm{O}_{3}$ (Inframat Advanced Materials), and $\mathrm{ZnO} / \mathrm{Al}_{2} \mathrm{O}_{3}$ (containing $10 \% \mathrm{~mol} \mathrm{Al}_{2} \mathrm{O}_{3}$ ) synthesized from the precipitation of $\mathrm{Zn}$ and $\mathrm{Al}$ following a variation of the method reported elsewhere ${ }^{41}$. For this, $12.34 \mathrm{~g} \mathrm{Zn}\left(\mathrm{CH}_{3} \mathrm{CO}_{2}\right)_{2}$ and $2.52 \mathrm{~g} \mathrm{Al}\left(\mathrm{NO}_{3}\right)_{2} \cdot 9 \mathrm{H}_{2} \mathrm{O}$ were dissolved in $60 \mathrm{ml}$ deionized water. Then $1 \mathrm{M} \mathrm{Na}_{2} \mathrm{CO}_{3}$ was added dropwise until a $\mathrm{pH}$ value of 9 was reached. After $1 \mathrm{~h}$, the solution was washed, filtered, and dried to obtain a white powder. In the final step, the powder was calcined at $600^{\circ} \mathrm{C}$. XRD analysis showed only reflections corresponding to zincite $(\mathrm{ZnO})$.

Temperatures for calcination and cleanliness (removal of polymeric carbon) after the calcination of the NPs supported on the oxide powders were determined by thermogravimetric analysis (TGA) (see Supplementary Figure 2). The catalysts were calcined for $6 \mathrm{~h}$ in a rotating tubular oven under a flow of $20 \% \mathrm{O}_{2}$ in $\mathrm{Ar}$ at the temperatures obtained from the TGA analysis.

The metal content of the synthesized powders (after calcination) was determined by inductively coupled plasma-mass spectrometry (ICP-MS). To prepare the samples for ICP, a precise amount of the calcined powder catalyst was dissolved in $10 \mathrm{ml}$ of a 1:1:3 mixture of $\mathrm{H}_{2} \mathrm{SO}_{4}, \mathrm{HNO}_{3}$, and $\mathrm{HCl}$. This solution was digested in a microwave (Anton Paar $\mathrm{GmbH}$, Multiwave GO) at $180^{\circ} \mathrm{C}$ for $30 \mathrm{~min}$. Then, the solution was further diluted with water. The results of the ICP measurements are given in Supplementary Table 2.

TEM imaging. TEM and STEM images of the samples before and after reaction were acquired using the microscopes at the Fritz Haber Institute (Thermo Fisher Talos F200X, JEOL ARM200F, operated at $200 \mathrm{kV}$ ) in Berlin, at the Ernst RuskaCentrum (FEI Titan 80-200, operated at $200 \mathrm{kV}$ ) in Jülich, and at the RuhrUniversity (JEOL JEM-2800) in Bochum. The samples after reaction were imaged by transferring them under inert atmosphere to a glove box and loading them onto Au grids with a holey carbon film. The samples were transferred to the Talos TEM using a vacuum transfer holder. This procedure ensured no exposure to air/ $\mathrm{O}_{2}$ after the reaction. For STEM analysis with a Cs-probe corrected FEI Titan 80-200 microscope, a probe semi-angle of $25 \mathrm{mrad}$ and an inner collection semi-angle of the detector of $88 \mathrm{mrad}$ were used to achieve high-angle-annular dark-field conditions. Compositional maps were obtained with EDX using four large-solid-angle symmetrical Si drift detectors. Additional STEM EDX maps are shown in Supplementary Figures 3-5.

XRD characterization. The XRD patterns were recorded using a Bruker-AXS D8 Advance diffractometer equipped with a $\mathrm{Cu} \mathrm{K}_{\alpha}$ source and a position-sensitive energy-dispersive LynxEye XE-T detector. XRD patterns were recorded in 
continuous scanning mode in a $2 \theta$ range of $20-90^{\circ}$, applying an increment $0.02^{\circ}$ and a variable divergence slit configuration ensuring constant sample illumination.

Rietveld refinement was performed using the software package TOPAS ${ }^{\varpi}$ (Bruker-AXS) to analyze the diffraction patterns taking into account instrumental broadening, zero error, and sample displacement. Owing to the structural complexity of the $\mathrm{Al}_{2} \mathrm{O}_{3}$, no Rietveld refinement was performed on the $\mathrm{CuZn}$ / $\mathrm{Al}_{2} \mathrm{O}_{3}$ diffraction pattern. Furthermore, the diffraction signals of the $\mathrm{SiO}_{2}$ support were considered as convolution of individual peaks, which made a Rietveld quantification impossible. The results of the XRD experiments are shown in Supplementary Figure 6 and Supplementary Tables 3-6.

Catalytic testing. The catalytic activity was measured in a high-pressure fixed-bed flow reactor. About $50 \mathrm{mg}$ of the catalyst were diluted with $\sim 300 \mathrm{mg} \mathrm{SiC}$ (ratio 6:1) and then placed in a glass-lined steel tube. Before testing, all catalysts were reduced by flowing $10 \% \mathrm{H}_{2}$ in $\mathrm{He}$ for $2 \mathrm{~h}$ at $245^{\circ} \mathrm{C}$. The activity was measured at pressures of 20,40 , and $60 \mathrm{bar}$ and temperatures of $220^{\circ} \mathrm{C}, 250^{\circ} \mathrm{C}$, and $280^{\circ} \mathrm{C}$. The reaction gas mixture consisted of a $10 \% \mathrm{CO}, 4 \% \mathrm{CO}_{2}, 72 \% \mathrm{H}_{2}$, and $14 \% \mathrm{He}$, which was used as an internal standard. The total flow was $17 \mathrm{ml} / \mathrm{min}$. The reaction products were measured online by gas chromatography (GC) with an Agilent Technologies 7890B gas chromatograph equipped with a flame ionization detector and two thermal conductivity detectors. All reported values are the average of at least three consecutive injections. A carbonyl trap was used to ensure that the catalyst remains $\mathrm{Ni}$ free. Our carbonyl trap consisted of a stainless steel tube filled with $\mathrm{SiC}$, which was heated up to $300^{\circ} \mathrm{C}$. The trap was placed on the $\mathrm{CO}$ line directly before the mixing with the other gases took place. The absence of $\mathrm{Ni}$ after reaction was confirmed by TEM-EDX.

The values for the methanol production are normalized using the $\mathrm{Cu}$ content (grams of $\mathrm{Cu}$ ) in the powder catalyst determined by ICP-MS. Supplementary Figure 7 shows additional results obtained during the catalytic measurements. The activity for each catalyst was measured in multiple consecutive reaction steps. After the reduction, the catalyst was cooled down to $220^{\circ} \mathrm{C}$ and the reactant mixture was introduced, then the reactor was pressurized to $20 \mathrm{bar}$. The reactivity was then measured at $220^{\circ} \mathrm{C}, 250{ }^{\circ} \mathrm{C}$, and $280^{\circ} \mathrm{C}$, each temperature step lasting for $8 \mathrm{~h}$. After this the catalyst was cooled down to $220^{\circ} \mathrm{C}$, before going to the next pressure. This procedure was repeated for the 40 bar and 60 bar data points, for a complete cycle of all reaction steps.

During the initial reaction steps, the catalytic activity was not stable, and a long activation period $(50-140 \mathrm{~h})$ was needed until the steady-state operation was achieved. The steady-state data for all catalysts are included in the main text (Fig. 5a) and in Supplementary Figure 7. The activity of the $\mathrm{Cu} / \mathrm{SiO}_{2}$ and $\mathrm{Cu} / \mathrm{ZnO} /$ $\mathrm{Al}_{2} \mathrm{O}_{3}$ catalysts was found to become stable relatively fast, since already during the step at 40 bar no major changes were observed. For the catalysts supported on $\gamma$ $\mathrm{Al}_{2} \mathrm{O}_{3}$, the stabilization took longer time, and the catalyst only showed stable methanol production values during the 60 bar reaction step. During the activation of the $\mathrm{Cu} / \mathrm{SiO}_{2}, \mathrm{Cu} / \mathrm{ZnO} / \mathrm{Al}_{2} \mathrm{O}_{3}, \mathrm{Cu} / \mathrm{Al}_{2} \mathrm{O}_{3}$, and $\mathrm{CuZn} / \mathrm{Al}_{2} \mathrm{O}_{3}$ catalysts, the production and selectivity toward methanol increases and they reach a steady state after the first cycle of all reaction conditions. The data displayed in Fig. 5 shows the results of a second cycle for all reaction conditions once the steady state was reached. However, the activation period is longer for the $\mathrm{CuZn} / \mathrm{SiO}_{2}$ catalyst than for the others, as it does not become stable during the first run through all reaction temperatures and pressures. For this reason, we stayed at one reaction condition $\left(280^{\circ} \mathrm{C}\right.$ and $40 \mathrm{bar}$ ) until a steady state was reached, which in this case took $150 \mathrm{~h}$ (see Fig. 5b). The same was done for the $\mathrm{CuZn} / \mathrm{Al}_{2} \mathrm{O}_{3}$ catalyst for comparison (see Fig. 5b). Using the knowledge gained from the operando XAS experiments, we can conclude that this slow change, which is accelerated at higher temperatures is related to the formation of a metallic $\mathrm{Zn}$ phase. Another unique feature of the activation of the $\mathrm{CuZn} / \mathrm{SiO}_{2}$ catalyst is that the methanol production first increases with time, as was the case for all the other catalysts, but then only for this catalyst the activity decreases after $\sim 50 \mathrm{~h}$. The subsequent reduction of the catalytic activity of the $\mathrm{CuZn} / \mathrm{SiO}_{2}$ sample can then be associated with the reduction of $\mathrm{Zn}$, which was only found to take place for this catalyst. The values given in Fig. 5a and Supplementary Figure 7 are collected after the activation period, during the steadystate operation, when no changes in activity over time were observed.

The empty reactor was also tested before each experiment to ensure the absence of any background contribution or residuals from previous measurements. In this test, the empty reactor was heated up and pressurized while flowing the reaction gas mixture. To further ensure the reliability of the measurements carried out here on low-metal loading NPs, a commercial copper-based methanol synthesis catalyst (Alfa Aesar, 45776) with a sieve fraction 100-200 $\mu \mathrm{m}$, was tested under the same conditions in our reactor, showing the high selectivity and yield expected for this high-copper loading sample (Supplementary Figure 8).

Operando XAS. The operando XAS measurements were performed at beamline 2-2 at SSRL (operando high-pressure experiments) and Quick X-ray Absorption and Scattering (QAS) beamline at NSLS-II synchrotron (ambient pressure/high temperature control experiments). Beryllium tube reactors (for measurements at pressures up to 40 bar) and quartz capillary reactors (for measurements at pressures up to 20 bar) were used to emulate the packed bed reactors used for the catalytic tests. The reactors were loaded with the sample, which was fixed in position with quartz wool plugs. The reactor was connected to a gas manifold, consisting of multiple mass flow controllers for precise gas dosing. A backpressure regulator adjusted the pressure in the reactor. The beryllium reactor was heated with a tubular oven with a window for the beam. This configuration only allows for measurements in transmission. The quartz reactors were heated with heating coils and enables, dependent on the configuration, measurements in fluorescence. The samples were diluted with boron nitride to optimize the absorption of the sample for transmission measurements. Control experiments at the QAS beamline were carried out in fluorescence mode using a PIPS detector. A 30\% detuned $\mathrm{Si}(220)$ double crystal monochromator was used for energy selection at SSRL, whereas a Si (111) monochromator was used at NSLS-II. The ionization chambers used as X-ray detectors for transmission measurements were filled with $\mathrm{N}_{2}$. Cu and $\mathrm{Zn}$ reference foils were also measured together with the spectra of the samples for energy calibration.

During the operando studies at SSRL, all samples were initially measured under $\mathrm{He}$ atmosphere and at room temperature to record their initial state. Subsequently, the $10 \% \mathrm{H}_{2} / \mathrm{He}$ mixture was dosed and the temperature was raised until the reduction temperature was achieved, which was kept for $2 \mathrm{~h}$. The reduction temperature was $245^{\circ} \mathrm{C}$ for the $\mathrm{Cu} / \mathrm{ZnO} / \mathrm{Al}_{2} \mathrm{O}_{3}$ and the $\mathrm{CuZn} / \mathrm{Al}_{2} \mathrm{O}_{3}$ catalysts and $325^{\circ} \mathrm{C}$ for the $\mathrm{CuZn} / \mathrm{SiO}_{2}$ catalyst. A higher activation temperature was used for the sample deposited on $\mathrm{SiO}_{2}$ in order to reduce the $\mathrm{CuO}_{\mathrm{x}}$ species, which were found to be more stable on this support. In a separate follow-up experiment (see below), we used $245^{\circ} \mathrm{C}$ activation temperature also for the $\mathrm{CuZn} / \mathrm{SiO}_{2}$ catalyst and obtained similar results as for the sample activated at $325^{\circ} \mathrm{C}$, thus the difference in activation temperatures is not crucial here.

Next, the temperature was lowered to $220^{\circ} \mathrm{C}$ and the reaction mixture $(10 \%$ $\mathrm{CO}, 4 \% \mathrm{CO}_{2}, 72 \% \mathrm{H}_{2}, 14 \% \mathrm{He}$ ) was introduced and the reactor was pressurized to the required working pressures, i.e., 20 and 40 bar. Heating rates of $5{ }^{\circ} \mathrm{C} / \mathrm{min}$ were used for all temperature changes. The reaction series consisted of: (i) 20 bar at $220^{\circ}$ C, (ii) 20 bar at $280^{\circ} \mathrm{C}$, (iii) 40 bar at $280^{\circ} \mathrm{C}$, and (iv) 40 bar at $320^{\circ} \mathrm{C}$. The last step at high temperature $\left(320^{\circ} \mathrm{C}\right)$ was performed in order to mimic an aging treatment. A mass spectrometer recorded the gaseous effluent of the reactor.

For the $\mathrm{CuZn} / \mathrm{SiO}_{2}$ sample, we performed additional experiments where the sample was activated at $245^{\circ} \mathrm{C}$ in a $\mathrm{H}_{2} / \mathrm{He}$ mixture at 1 bar for $2 \mathrm{~h}$. The sample was then cooled down to room temperature, and XAS spectra were recorded at room temperature to obtain high-quality data that are not obstructed by high thermal disorder. Subsequently, the sample was exposed to reaction conditions $\left(220^{\circ} \mathrm{C}\right.$ and 20 bar) for $2 \mathrm{~h}$, then depressurized and cooled down to room temperature, where XAS spectra were also recorded.

Moreover, in a separate experiment we followed the reduction of the $\mathrm{CuZn} / \mathrm{SiO}_{2}$ sample during a long-term treatment, where the sample was kept at $245^{\circ} \mathrm{C}$ in a $\mathrm{H}_{2} /$ $\mathrm{He}$ mixture (at atmospheric pressure) for $20 \mathrm{~h}$. Afterwards, the sample cell was cooled down to room temperature, where XAS spectra were collected.

Finally, at the QAS beamline we also performed control experiments for the $\mathrm{CuZn} / \mathrm{SiO}_{2}$ sample, where the sample was kept in a $\mathrm{H}_{2} / \mathrm{He}$ mixture at $1 \mathrm{bar}$, and the temperature was gradually increased from $245^{\circ} \mathrm{C}$ to $320^{\circ} \mathrm{C}$, then to $450{ }^{\circ} \mathrm{C}$ and $600{ }^{\circ} \mathrm{C}$, to enhance the reduction of the $\mathrm{Zn}$ species.

In situ NAP-XPS. The NPs for the NAP-XPS study were synthesized using the same method described above, using a PS-P2VP $(48,500: 70,000)$ polymer to obtain the micelles. Deposition of the particles on the $\mathrm{SiO}_{2} / \mathrm{Si}(100)$ support was done by dip coating $(1 \mathrm{~cm} / \mathrm{min})$. The polymer ligands were removed by an $\mathrm{O}_{2}$ plasma treatment (SPI Plasma Prep III Plasma Etcher, 20 min, 20 W, 350 mTorr). The procedure of dip-coating and plasma treatment was repeated three times to increase the density of particles on the support. The particle size and distribution on the $\mathrm{SiO}_{2} / \mathrm{Si}(100)$ was measured by AFM. The NP height values were obtained with the open-source software Gwyddion (Supplementary Figure 19).

The NAP-XPS measurements with synchrotron radiation were performed at the HIPPIE beamline of the MAX IV synchrotron in Lund (Sweden) and the IOS beamline at NSLS-II in Brookhaven (NY, USA). Additional lab-based NAP-XPS measurements were carried out at the FHI Berlin using $\mathrm{Al} \mathrm{K}_{\alpha}$ radiation and a hemispherical analyzer (Phoibos 150, SPECS GmbH). The synchrotron measurements were performed at X-ray energies of $1250 \mathrm{eV}$ and $1580 \mathrm{eV}$ to obtain a depth profile, as different kinetic energies result in different escape depths of the photoelectrons. $1250 \mathrm{eV}$ corresponds to an IMFP of $\sim 0.8 \mathrm{~nm}$ for $\mathrm{Cu} 2 p$ and $0.7 \mathrm{~nm}$ for $\mathrm{Zn} 2 p$ photoelectrons, probing the outermost layers of the NPs, and $1580 \mathrm{eV}$ corresponds to $\sim 1.2 \mathrm{~nm}$ for $\mathrm{Cu} 2 p$ and $\mathrm{Zn} 2 p$, thus probing deeper regions ${ }^{33}$. The energy values were chosen to avoid overlap with peaks resulting from the Auger electrons. The LMM X-ray generated Auger regions for $\mathrm{Cu}$ and $\mathrm{Zn}$ were also recorded. All peaks were aligned to the elemental Si $2 p_{3 / 2}$ peak at a BE of $99.4 \mathrm{eV}$ The Si peak itself was fitted using a doublet, with an energy splitting of $0.6 \mathrm{eV}$. For the quantification of the elemental composition at given photon energy, the peaks of the $\mathrm{Cu} 2 p_{3 / 2}$ and $\mathrm{Zn} 2 p_{3 / 2}$ regions were fitted. The obtained values were corrected with the relative sensitivity factors of the different elements. For quantitative analysis of the peak area, the IMFP and ionization cross-section for the corresponding photon energy were taken into account.

The series of NAP-XPS measurements were as follows: the first step was oxidation in pure $\mathrm{O}_{2}\left(0.13 \mathrm{mbar}\right.$ at $\left.400{ }^{\circ} \mathrm{C}\right)$ to remove any adventitious carbon on the surface of the sample. The $\mathrm{C} 1 \mathrm{~s}$ peak was monitored during the oxidation and the experiment only continued when no traces of carbon were detected. This was followed by a reduction in $\mathrm{H}_{2}\left(1.3 \mathrm{mbar}, 350^{\circ} \mathrm{C}\right)$ for the activation of the catalyst by 
reduction of the $\mathrm{Cu}$ and afterwards, the reaction gas mixture $\left(1.3 \mathrm{mbar}, 250^{\circ} \mathrm{C}\right)$ was introduced. The measurements were carried out under different reaction mixtures, whose concentrations are shown in Supplementary Table 7. Between each of these steps, the sample was cooled down in the gas atmosphere to near room temperature, then the chamber was evacuated, and filled with the new gas before heating up. For each reaction mixture, a new measurement series was performed introducing an identically prepared but fresh sample.

An important aspect to be considered when synchrotron NAP-XPS investigations are conducted is the strong influence of the X-ray beam on the sample (Supplementary Figure 20). During the measurements in a gas atmosphere, besides the reversible surface segregation discussed in the main text, irreversible radiation-induced segregation trends were also observed. In fact, we detected the loss of the metal segregating to the surface (e.g., $\mathrm{Cu}$ in $\mathrm{O}_{2}$ atmosphere, and $\mathrm{Zn}$ in $\mathrm{H}_{2}$ atmosphere and under the reaction gas mixture) when the X-ray beam stayed on the same spot of the sample surface for several minutes. To avoid any radiationinduced effects on our results, the spot on the sample was changed to a new, fresh location after each set of scans and the $\mathrm{Cu} 2 p$ and $\mathrm{Zn} 2 p$ regions were measured in alternating order in consecutive rounds of measurements. The reproducibility and reliability of the results presented here was confirmed in a large number of independent measurements at the synchrotron, as well as analogous investigations with a lab-based NAP-XPS system.

\section{Data availability}

All data are available from the authors on reasonable request.

Received: 23 October 2020; Accepted: 1 February 2021;

Published online: 04 March 2021

\section{References}

1. Behrens, M. et al. The active site of methanol synthesis over $\mathrm{Cu} / \mathrm{ZnO} / \mathrm{Al}_{2} \mathrm{O}_{3}$ industrial catalysts. Science 336, 893-897 (2012).

2. Kuld, S. et al. Quantifying the promotion of $\mathrm{Cu}$ catalysts by $\mathrm{ZnO}$ for methanol synthesis. Science 352, 969-974 (2016).

3. Kattel, S. et al. Active sites for $\mathrm{CO}_{2}$ hydrogenation to methanol on $\mathrm{Cu} / \mathrm{ZnO}$ catalysts. Science 355, 1296-1299 (2017).

4. Van Den Berg, R. et al. Structure sensitivity of $\mathrm{Cu}$ and $\mathrm{CuZn}$ catalysts relevant to industrial methanol synthesis. Nat. Commun. 7, 13057 (2016).

5. Studt, $\mathrm{F}$. et al. The mechanism of $\mathrm{CO}$ and $\mathrm{CO}_{2}$ hydrogenation to methanol over Cu-based catalysts. ChemCatChem 7, 1105-1111 (2015).

6. Kunkes, E. L. et al. Hydrogenation of $\mathrm{CO}_{2}$ to methanol and $\mathrm{CO}$ on $\mathrm{Cu} / \mathrm{ZnO} /$ $\mathrm{Al}_{2} \mathrm{O}_{3}$ : is there a common intermediate or not? J. Catal. 328, 43-48 (2015).

7. Behrens, M. Promoting the synthesis of methanol: understanding the requirements for an industrial catalyst for the conversion of $\mathrm{CO}_{2}$. Angew. Chem. Int. Ed. 55, 14906-14908 (2016).

8. Zander, S. et al. The role of the oxide component in the development of copper composite catalysts for methanol synthesis. Angew. Chem. Int. Ed. 52, 6536-6540 (2013).

9. Naumann D'Alnoncourt, R. et al. The influence of strongly reducing conditions on strong metal-support interactions in $\mathrm{Cu} / \mathrm{ZnO}$ catalysts used for methanol synthesis. Phys. Chem. Chem. Phys. 8, 1525-1538 (2006).

10. Wagner, J. B. et al. In situ electron energy loss spectroscopy studies of gasdependent metal-support interactions in $\mathrm{Cu} / \mathrm{ZnO}$ catalysts. J. Phys. Chem. B 107, 7753-7758 (2003).

11. Lunkenbein, $\mathrm{T}$. et al. Formation of a $\mathrm{ZnO}$ overlayer in industrial $\mathrm{Cu} / \mathrm{ZnO} /$ $\mathrm{Al}_{2} \mathrm{O}_{3}$ catalysts induced by strong metal-support interactions. Angew. Chem. Int. Ed. 127, 4627-4631 (2015).

12. Kuld, S. et al. Quantification of zinc atoms in a surface alloy on copper in an industrial-type methanol synthesis catalyst. Angew. Chem. - Int. Ed. 53, 5941-5945 (2014).

13. Zabilskiy, M. et al. The unique interplay between copper and zinc during catalytic carbon dioxide hydrogenation to methanol. Nat. Commun. 11, 1-8 (2020).

14. Palomino, R. M. et al. Hydrogenation of $\mathrm{CO} 2$ on $\mathrm{ZnO} / \mathrm{Cu}(100)$ and $\mathrm{ZnO} / \mathrm{Cu}$ (111) catalysts: role of copper structure and metal-oxide interface in methanol synthesis. J. Phys. Chem. B 122, 794-800 (2018).

15. Kandemir, T. et al. In Situ study of catalytic processes: Neutron diffraction of a methanol synthesis catalyst at industrially relevant pressure. Angew. Chem. Int. Ed. 52, 5166-5170 (2013).

16. Divins, N. J. et al. Influence of the support on surface rearrangements of bimetallic nanoparticles in real catalysts. Science 346, 620-623 (2014).

17. Grunwaldt, J. D. et al. In situ investigations of structural changes in $\mathrm{Cu} / \mathrm{ZnO}$ catalysts. J. Catal. 194, 452-460 (2000).

18. Clausen, B. S. \& Topsøe, H. In Situ high pressure, high temperature XAFS studies of $\mathrm{Cu}$-based catalysts during methanol synthesis. Catal. Today $\mathbf{9}$, 189-196 (1991).
19. Grandjean, D. et al. Dynamic $\mathrm{Cu} / \mathrm{Zn}$ interaction in $\mathrm{SiO}_{2}$ supported methanol synthesis catalysts unraveled by in situ XAFS. J. Phys. Chem. C. 115, 20175-20191 (2011).

20. Van Den Berg, M. W. E. et al. Dynamical changes in the $\mathrm{Cu}-\mathrm{ZnO}_{\mathrm{x}}$ interaction observed in a model methanol synthesis catalyst. Catal. Lett. 128, 49-56 (2009).

21. Großmann, D. et al. Surface alloy or metal-cation interaction-the state of $\mathrm{Zn}$ promoting the active $\mathrm{Cu}$ sites in methanol synthesis catalysts. ChemCatChem 9, 365-372 (2017)

22. Bansode, A. et al. Performance and characteristics of a high pressure, high temperature capillary cell with facile construction for operando $\mathrm{x}$-ray absorption spectroscopy. Rev. Sci. Instrum. 85, 084105 (2014).

23. Clausen, B. S. et al. Wetting/non-wetting phenomena during catalysis: evidence from in situ on-line EXAFS studies of $\mathrm{Cu}$-based catalysts. Top. Catal. 1, 367-376 (1994)

24. Martin, O. et al. Operando Synchrotron X-ray powder diffraction and modulated-excitation infrared spectroscopy elucidate the $\mathrm{CO}_{2}$ promotion on a commercial methanol synthesis catalyst. Angew. Chem. 128, 11197-11202 (2016).

25. Laudenschleger, D. et al. Identifying the nature of the active sites in methanol synthesis over $\mathrm{Cu} / \mathrm{ZnO} / \mathrm{Al}_{2} \mathrm{O}_{3}$ catalysts. Nat. Commun. 11, 1-10 (2020).

26. Kniep, B. L., Girgsdies, F. \& Ressler, T. Effect of precipitate aging on the microstructural characteristics of $\mathrm{Cu} / \mathrm{ZnO}$ catalysts for methanol steam reforming. J. Catal. 236, 34-44 (2005).

27. Koitaya, T. et al. $\mathrm{CO}_{2}$ activation and reaction on $\mathrm{Zn}$-deposited $\mathrm{Cu}$ surfaces studied by ambient-pressure X-ray photoelectron Spectroscopy. ACS Catal. 9 , 4539-4550 (2019).

28. Hansen, P. L. et al. Atom-resolved imaging of dynamic shape changes in supported copper nanocrystals. Science 295, 2053-2055 (2002).

29. Qi, W. H., Wang, M. P. \& Liu, Q. H. Shape factor of nonspherical nanoparticles. J. Mater. Sci. 40, 2737-2739 (2005).

30. Calvin, S. et al. Determination of crystallite size in a magnetic nanocomposite using extended x-ray absorption fine structure. J. Appl. Phys. 94, 778-783 (2003).

31. Camacho-Bunquin, J. et al. Single-site zinc on silica catalysts for propylene hydrogenation and propane dehydrogenation: synthesis and reactivity evaluation using an integrated atomic layer deposition-catalysis instrument. J. Catal. 345, 170-182 (2017)

32. Mekprasart, W. et al. Characterization and effect of calcination temperature on structural properties of spinel zinc aluminate synthesized via $\mathrm{Co}-$ precipitation process. Phys. Status Solidi Curr. Top. Solid State Phys. 12, 624-627 (2015)

33. Powell, C. J. \& Jablonski, A. NIST Electron Inelastic-Mean-Free-Path database - Version 1.2. (National Institute of Standards and Technology, 2010).

34. Yang, $\mathrm{Y}$. et al. Mechanistic studies of methanol synthesis over $\mathrm{Cu}$ from $\mathrm{CO} /$ $\mathrm{CO}_{2} / \mathrm{H}_{2} / \mathrm{H}_{2} \mathrm{O}$ mixtures: the source of $\mathrm{C}$ in methanol and the role of water. $J$. Catal. 298, 10-17 (2013).

35. Biesinger, M. C. et al. Resolving surface chemical states in XPS analysis of first row transition metals, oxides and hydroxides: $\mathrm{Sc}, \mathrm{Ti}, \mathrm{V}, \mathrm{Cu}$ and $\mathrm{Zn}$. Appl. Surf. Sci. 257, 887-898 (2010).

36. Holse, C. et al. Dynamic behavior of CuZn nanoparticles under oxidizing and reducing conditions. J. Phys. Chem. C. 119, 2804-2812 (2015).

37. Schott, V. et al. Chemical activity of thin oxide layers: strong interactions with the support yield a new thin-film phase of $\mathrm{ZnO}$. Angew. Chem. Int. Ed. 52, 11925-11929 (2013).

38. Gentzen, M. et al. Bifunctional catalysts based on colloidal $\mathrm{Cu} / \mathrm{Zn}$ nanoparticles for the direct conversion of synthesis gas to dimethyl ether and hydrocarbons. Appl. Catal. A Gen. 557, 99-107 (2018).

39. Lam, E. et al. $\mathrm{CO}_{2}$ hydrogenation on $\mathrm{Cu} / \mathrm{Al}_{2} \mathrm{O}_{3}$ : role of the metal/support interface in driving activity and selectivity of a bifunctional Catalyst. Angew. Chem. Int. Ed. 58, 13989-13996 (2019).

40. Arena, F. et al. Synthesis, characterization and activity pattern of $\mathrm{Cu}-\mathrm{ZnO} /$ $\mathrm{ZrO}_{2}$ catalysts in the hydrogenation of carbon dioxide to methanol. J. Catal. 249, 185-194 (2007).

41. Behrens, M. et al. Performance improvement of nanocatalysts by promoterinduced defects in the support material: Methanol synthesis over $\mathrm{Cu} / \mathrm{ZnO}: \mathrm{Al}$. J. Am. Chem. Soc. 135, 6061-6068 (2013).

\section{Acknowledgements}

This work was funded by the European Research Council under grant ERCOPERANDOCAT (ERC-725915) and the Forschungsgemeinschaft (DFG) under Germany's Excellence Strategy-EXC 2008 - 390540038-UniSysCat and EXC 1069 RESOLV. The majority of the XAS work was performed at Stanford Synchrotron Radiation Lightsource (beamline 2-2) of SLAC National Accelerator Laboratory, supported by the Office of Basic Energy Sciences of the US Department of Energy (DOE) under Contract No. DE-AC02-76SF00515 and by Co-ACCESS (Chemical Sciences, Geosciences, and Biosciences Division). Additional studies were carried out at the National Synchrotron Light Source II (NSLS-II, IOS and QAS beamlines) of Brookhaven 
National Laboratory supported by DOE under Contract No. DE-SC0012704. We also acknowledge MAX IV Laboratory (Sweden) for access to the Beamline HIPPIE and Andrey Shavorskiy for his assistance during the NAP-XPS measurements. Max IV is funded by the Swedish Research council under contract 2018-07152, the Swedish Governmental Agency for Innovation Systems under contract 2018-04969, and Formas under contract 2019-02496. We further thank Olaf Timpe, Stephanie Kühl, and Frank Girgsdies (FHI) for the ICP and some of the XRD measurements and Alba Titze Alonso (RUB) for her assistance with sample preparation.

\section{Author contributions}

N.J.D and D.K. contributed equally to this work. N.J.D and B.R.C. conceived the project. N.J.D. and D.K. synthesized and characterized the catalysts (AFM, TGA, XPS) and performed the catalytic measurements. S.W. helped with the sample synthesis and preparation. N.J.D., S.W.C., M.H. performed TEM measurements. N.J.D, D.K., J.T., I.S., H.M, M.L.L., A.H, and A.Bo. carried out the XAS experiments. J.T., N.J.D, I.S. and B.R.C. interpreted the XAS data. N.J.D., D.K., I.Z., O.K., M.L.L., J.Q.Z., and J.A.B. carried out the NAP-XPS measurements, which were interpreted by N.J.D., D.K., I.Z. and B.R.C. A.Be. was responsible for XRD measurement and analysis. N.J.D, D.K., J.T., and B.R.C. wrote the original manuscript. All authors discussed and commented on the manuscript. S.B., R.D., and B.R.C. were providing the resources. B.R.C. obtained the funding and administrated the project.

\section{Funding}

Open Access funding enabled and organized by Projekt DEAL.

\section{Competing interests}

The authors declare no competing interests.

\section{Additional information}

Supplementary information The online version contains supplementary material available at https://doi.org/10.1038/s41467-021-21604-7.

Correspondence and requests for materials should be addressed to B.R.C.

Peer review information Nature Communications thanks the anonymous reviewer(s) for their contribution to the peer review of this work.

Reprints and permission information is available at http://www.nature.com/reprints

Publisher's note Springer Nature remains neutral with regard to jurisdictional claims in published maps and institutional affiliations.

(c) (i) Open Access This article is licensed under a Creative Commons Attribution 4.0 International License, which permits use, sharing, adaptation, distribution and reproduction in any medium or format, as long as you give appropriate credit to the original author(s) and the source, provide a link to the Creative Commons license, and indicate if changes were made. The images or other third party material in this article are included in the article's Creative Commons license, unless indicated otherwise in a credit line to the material. If material is not included in the article's Creative Commons license and your intended use is not permitted by statutory regulation or exceeds the permitted use, you will need to obtain permission directly from the copyright holder. To view a copy of this license, visit http://creativecommons.org/ licenses/by/4.0/.

(C) The Author(s) 2021 